\title{
The prosodic structure of prefixed words in the history of West Germanic*
}

\section{Paula Fikkert}

\section{Introduction}

Prefixes have long been recognized as disturbing factors in analyses of the prosodic structures of words in the history of West Germanic languages. Disregarding prefixed words, main stress in the older stages of the West Germanic languages was uncontroversially assigned to the first syllable of the word or root. However, prefixed words behave notoriously difficult: although all handbooks give as a rule of thumb that prefixed nouns have stress on the prefix, and prefixed verbs stress on the root, the exceptions to this rule are numerous, as we will see in section 2 . Given this complex situation regarding stress in prefixed words in the older stages of the languages, it is of interest to investigate how prefixed loan words entered the different languages in the middle period, where the situation in English will be compared to that of the sister language Dutch. In section 3, we will sketch how unprefixed Romance loans, derived and underived, entered the English and Dutch language.

In section 4, we will discuss the borrowing of word pairs of the type abstráct $_{\mathrm{V}}$ - ábstract ${ }_{\mathrm{N}}$, which in English differ in stress patterns and morphosyntactic class. These word pairs have evoked substantial research in both phonology and morphology (cf. Jespersen 1909, Kingdon 1958, Chomsky \& Halle 1968, Halle \& Keyser 1971, Aronoff 1976, Kiparsky 1982, Minkova 1997). The concern of this paper is not to show how different theories account for these facts (cf. Redford, this volume, McCully, this volume). Rather, it aims to clarify how word pairs like abstráct $t_{\mathrm{V}}$ ábstract $_{\mathrm{N}}$ first arose. After the Norman Conquest many Romance words entered the English lan- 
guage. Some examples are given in (1). The dates given in (1), and elsewhere for English words, denote the first occurrence of a word according to the OED.

(1) Romance disyllabic loans into English

Nouns

a. íncline (1600) ímpress (1590)

tránsport (1456)

cónflict (1440)

cómbine (1610)

éxport (1690)

cóntrast (1597)

ímport (1588)

áccent (1581)

b. présent (1225)

púrport (1278)

cónduct (1290)

ábsent (1382)

cóntract (1386)

ábstract (1387)

prótest (1400)

próject (1400)

$\begin{array}{ll}\begin{array}{l}\text { Verbs } \\ \text { inclíne }\end{array} & (1300) \\ \text { impréss } & (1374) \\ \text { transpórt } & (1374) \\ \text { conflíct } & (1432) \\ \text { combíne } & (1440) \\ \text { expórt } & (1485) \\ \text { contrást } & (1490) \\ \text { impórt } & (1508) \\ \text { accént } & (1530) \\ \text { presént } & (1290) \\ \text { purpórt } & (1300) \\ \text { condúct } & (1400) \\ \text { absént } & (1400) \\ \text { contráct } & (1548) \\ \text { abstráct } & (1542) \\ \text { protést } & (1440) \\ \text { projéct } & (1477)\end{array}$

Since the word pairs in (1) are all loan words, the question is when and how did these words enter the language.

A straightforward analysis for the facts in (1) would be that they are borrowed and incorporated analogous to the Old English nounverb pairs, as suggested by Sweet (1891) and Jespersen (1909), and this analysis will also be defended in this paper in section 4 . This view, however, is explicitly denied in the influential work of Halle \& Keyser (1971) and more recently, and more subtle, in Minkova (1997). In section 5 we will see that, rather than account for the patterns in (1) by analogy, both argue that the Old English stress system changed under influence of loan words, although they account for the change in different ways. 
In section 6, we will compare the way in which Romance loans entered into English with the situation in Middle Dutch. Here too, I will argue that foreign words were incorporated into the native prosodic system, in both English and Dutch; neither did they enter the language initially with their foreign stress pattern, nor did these words immediately lead to a change into the prosodic system of the language. However, small differences in the prosodic systems of English and Dutch at the time of borrowing lead to different prosodic structures for borrowed nouns and verbs. Unlike in English, as shown in (1), Romance nouns were usually borrowed with final stress in Dutch, because the language allowed final stressed syllables. However, Romance verbs were borrowed with a stressed verbal derivational ending. Some examples are given in (2).

(2) Romance loans into Dutch

$\begin{array}{lllll}\begin{array}{l}\text { Nouns } \\ \text { advíes }\end{array} & (1265-1270)^{1} & \begin{array}{l}\text { Verbs } \\ \text { adviséren }\end{array} & (1467-1490) & \text { 'advise' } \\ \text { presént } & (1240) & \text { presentéren } & (1240) & \text { 'present' } \\ \text { arrést } & (1308-1346) & \text { arrestéren } & (1276-1300) & \text { 'arrest' } \\ \text { appél } & (1336-1339) & \text { appeléren } & (1281) & \text { 'appeal' } \\ \text { adrés } & (1574) & \text { adresséren } & (1512) & \text { 'address' } \\ \text { dispúut } & (1566) & \text { disputéren } & (1240) & \text { 'dispute' } \\ \text { excúus } & (1546) & \text { excuséren } & (1353) & \text { 'excuse' } \\ \text { protést } & (1582) & \text { protestéren } & (1400) & \text { 'protest' } \\ \text { transpórt } & (1506) & \text { transportéren } & (1503) & \text { 'transport' } \\ \text { accént } & (1240) & \text { accentuéren not given } & \text { 'accent' } \\ \text { contráct } & (1391) & \text { contractéren } & \text { not given } & \text { 'contract' } \\ \text { projéct } & (1613) & \text { projectéren } & (1650) & \text { 'project' } \\ \text { profijt } & (1265) & \text { profitéren } & (1451) & \text { 'profit' } \\ \text { prodúct } & (1508)^{2} & \text { producéren } & (1697) & \text { 'produce' }\end{array}$

Besides differences in the prosodic systems of English and Dutch, there are also important morphological and syntactic differences between the two in the middle stages of the languages. Although both Dutch and English had two types of prefixed verbs in the older period - separable prefixed verbs with stress on the prefix, and inseparable prefixed verbs with stress on the verb root - Middle English unlike Middle Dutch - no longer had separable prefixed verbs: ME upstart corresponds to ModE to start up (cf. Marchand 1969, Strang 
1970, Hiltunen 1983). Separable prefixed verbs have largely been replaced by simple verbs followed by a post-particle ${ }^{3}$ or by a Romance loans. The explanation for the decline of separable prefixed verbs is usually accounted for by the change of word order from SOV to SVO. ${ }^{4}$ Thus, this is in principle unrelated to the decline of inseparable prefixed verbs. Not only were separable prefixed verbs lost, there also was a decline in inseparable prefixed verbs in English. The common understanding of the decline of inseparable prefixed verbs is that the unstressed prefixed eroded, ${ }^{5}$ just like unstressed endings, whereby the unstressable prefixes like ge-, were the first ones to disappear. ${ }^{6}$

However, there are at least two problems with this account. First, while native verbs with inseparable unstressed prefixes were on the decline in English, there was the rise of loan words with inseparable and unstressed prefixes, particularly the prefixed verbs in (1), which remains to be explained (cf. Strang 1970: 191, Samuels 1972: 164, Lutz 1997). ${ }^{7}$ Second, a language like Dutch, which has also lost many morphological endings in the course of its history, has nevertheless retained its unstressed verbal prefixes. Prefixes' lack of stress, therefore, cannot be a sufficient motivation for losing prefixes altogether.

Finally, Dutch did not borrow the Romance loans analogous to the native prefixed nouns and verbs, for several reasons. First, the prosodic system was preferring final stress on (super)heavy syllables, which caused Romance nouns to have final stress. Second, the distinction between nouns and verbs on the basis of stress was far less clear in Dutch than in English, due to the coexistence of stressed and unstressed prefixed verbs. Dutch nevertheless maintained a distinction between verbs and nouns from Romance by borrowing the Romance stressed infinitival suffix. Neither verbs nor nouns behave as being prefixed in Dutch. Unlike in English, the Romance prefixes never became productive in Dutch.

To summarize, the paper is organized as follows. In section 2 the special role of prefixes in the older stages of the West Germanic prosodic system is briefly discussed. Section 3 presents previous accounts of how Romance loans entered the English language. Section 4 gives arguments for the analogy analysis for Romance word pairs such as those in (1). Section 5 presents previous accounts for the 
different stress patterns in Romance nouns and verbs. In section 6 it will be shown that the subtle differences in the prosodic systems of Middle English and Middle Dutch can account for the differences in the way loans were borrowed in the two languages. Moreover, also differences in morphology and syntax between the two languages play a role in explaining the differences. Finally, section 7 summarizes the main conclusions.

\section{Prefixes in the word prosodic systems of older West Germanic}

\subsection{Stress on prefixed words in the history of English and Dutch}

Although prefixes have received considerable attention in phonology, morphosyntax and semantics (cf. Hiltunen 1983, Brinton 1988, Kastovsky 1996, Lutz 1997), their role in prosody has been underresearched. The prosodic systems of the West Germanic languages of which I shall only refer to English and Dutch - have changed dramatically over time (cf. Lahiri et al. 1999). Whereas the modern languages all are claimed to have main stress assigned from end of words (cf. Kager 1989, Hayes 1995, Zonneveld et al. 1999), in the older stages of these languages stress was basically root-initial (cf. Kluge 1891, Streitberg et al. 1936, Van Loey 1970, Krahe \& Meid 1969, Van Bree 1977, 1987, Suphi 1988, McCully \& Hogg 1990) or word-initial (cf. Kuhn 1863, Scherer 1878, Franck 1910, Hammerich 1921, Wright \& Wright 1925, 1928, Halle \& Keyser 1971). Thus, some researchers regard unstressed prefixes to be an anomaly to the otherwise straightforward analysis of word-initial main stress, while others view stressed prefixes as anomalous to the otherwise regular analysis of root or stem initial stress. From this description it is clear that prefixes obscure the regular pattern of initial stress.

The controversy in the literature about whether Old English stress is phonological or morphological is also largely due to 'misbehaving' prefixes. Suphi (1988), for instance, claims that stress is morphologically determined: prefixes to nouns are attached at level 1 , and undergo the stress rules (leading to word-initial stress), while prefixes to verbs are attached at level 2, i.e. after stress assignment. 
McCully \& Hogg (1990), on the contrary, argue that prefixes to verbs are extrametrical and are invisible for stress assignment. Minkova (1997) and Minkova \& Stockwell (1994) have also argued that stress is morphological in Old English. Under this view, prefixes in nouns are considered part of the root. Halle \& Keyser (1971) assume that stress in Old English was root-initial, but that prefixed nouns underwent a Stress Retraction Rule. We will discuss this analysis in more detail in section 5.1.

Although main stress was on the root in most prefixed verbs and on the prefix in most prefixed nouns (3a), Old English also had verbs with stress on prefixes. First, in the oldest period of the language, compound verbs had stress on the first element if the verbs was separable (Wright \& Wright, 1925: §14), as in (3b). Already in Old English these separable verbs were declining and they no longer exist in Middle and Modern English. Second, some verbs were derived from nouns, and kept initial stress, as in the case of ándswàrian 'to answer' from the noun ándswàru 'answer', as in (3c). Third, some prefixes like ge-were considered unstressable. These never bore stress, independent of whether they were prefixed to nouns or verbs, as shown in (3d). Most of these prefixes no longer exist in Modern English. Fourth, already in the oldest period of the language many nouns were formed from verbs containing an inseparable particle. Accordingly, these had main stress on the second element (Wright \& Wright 1925: §12), as shown in (3e). These forms, too, are declining in Old and Middle English. The patterns in (3) were found in the older stages of all West Germanic languages, and all of them are still attested in Modern Dutch, as shown in (4).

(3) Prefixed words in OE

Nouns

a. ándgiet

ándsaca

bīgang

wíersàca

b. 'æfterfòlgere fóresprèca
Verbs

ongíetan

onsácan

begángan

wipsácan

'æfterfôlgian

'æftersprècan 'to under-

stand"

'to deny'

'to practice'

'to oppose'

'to pursue'

'to claim' 


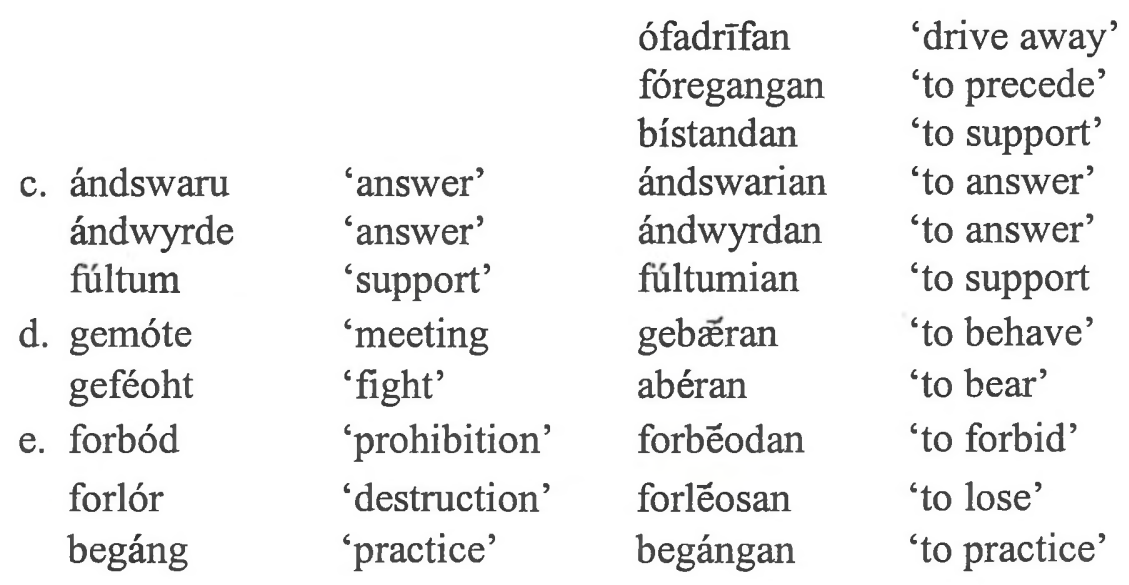

(4) Prefixed words in Modern Dutch

Nouns

a. wéerstand

b. bíjstand

c. ántwoord

d. gelóof

e. verlíes

'resistance'
'support'
'answer'
'believe'
'loss'

Verbs

$\begin{array}{ll}\text { weerstáan } & \text { 'to resist' } \\ \text { bíjstaan } & \text { 'to support' } \\ \text { ántwoorden } & \text { 'to answer' } \\ \text { gelóven } & \text { 'to believe } \\ \text { verlíezen } & \text { 'to lose' }\end{array}$

The role that prefixes play in determining the prosodic structure of words is far from obvious.

\subsection{Word stress in the history of English and Dutch}

There is also little consensus on the prosodic structure of unprefixed words of Old and Middle English. That main stress was largely initial in Old English is hardly controversial, but there are large disagreements on the location of secondary stress, and on the exact foot structure of Old English. While most scholars claim that Old English was not a quantity-sensitive language (cf. Halle \& Keyser 1971, Minkova \& Stockwell 1994, Minkova 1997), others have argued that stress in Old English was quantity-sensitive (Dresher \& Lahiri 1991, Lahiri \& Dresher 1999, Lahiri et al. 1999, and Lahiri \& Fikkert 1999). Under the latter view, Dresher \& Lahiri (1991) have proposed 
the Germanic foot, which is characterized as a foot whose head must contain two moras. Weight was entirely straightforward: syllables with long vowels and closed syllables are bimoraic. If the first syllable of the word is a light monomoraic syllable, it forms the head of the foot with the following syllable, whether light or heavy. This results in a resolved moraic trochee, as shown in (5):

(5) The Germanic Foot (Dresher \& Lahiri 1991)

Foot type: resolved expanded moraic trochee $([\mu \mu(\mu)] \mu)$

Direction of parsing: left to right

Main stress: Left

Sample parsings

$\begin{array}{ccc}(\mathrm{x} \quad) & (\mathrm{x} \quad .) & (\mathrm{x} \quad .) \\ ([\mu \mu] \mu) & ([\mu \mu] \mu) & ([\mu \mu \mu] \mu) \\ \mathrm{H} \mathrm{L} & \mathrm{LL} \mathrm{L} & \text { L H L } \\ \text { wor da } & \text { we ru da } & \text { cy nin ga }\end{array}$

Feet were built iteratively from left to right, and main stress was assigned to the first foot. The arguments for the Germanic foot come from main and secondary stress, High Vowel Deletion in Old English and Sievers' Law in Gothic. Other important features of Old English stress is that unstressed syllables never had long vowels, i.e. were usually light, and final syllables never bore stress. Dresher \& Lahiri argue that final feet underwent Final Defooting, which defooted feet without a dependent syllable (non-branching feet), which ultimately led to consonant extrametricality, as argued by Lahiri et al. (1999) and Lahiri \& Fikkert (1999). No provision is made for the treatment of prefixed words as these words were left out of the analysis.

\section{The prosodic structure of trisyllabic loans into Middle English}

Lahiri \& Fikkert (1999) provide additional evidence for the Germanic foot in Old and Middle English from loan word phonology. They discuss the phenomenon of Trisyllabic Shortening, which applied to native words in Old English, as shown in (6a), as well as in Romance loan words into Middle English, as shown in (6b). The 
singular (6a) and the 'underived' forms (6b) have a long vowel, whereas their corresponding forms to the right, respectively the plural and 'derived' forms, have a short vowel.

(6) TSS

a. Late Old English

Singular

$\begin{array}{ll}\text { Plural } & \\ \text { cǐcenu } & \text { 'chicken' } \\ \text { hěafodu } & \text { 'head' } \\ \text { æ̌nige } & \text { 'any' } \\ \text { clǎvere } & \text { 'clover' } \\ \text { hæ̌ringas } & \text { 'herring' }\end{array}$

cīcen

hēafod

ǣnig

clōver

hæ̈ring

hæ̌ringas

'herring'

b. Romance loans into Middle English (from Lahiri \& Fikkert 1999)

$\begin{array}{lll}\text { sāne } & (1628) & \text { sănity } \\ \text { vāin } & (1300) & \text { vănity } \\ \text { chāste } & (1225) & \text { chăstete } \\ \text { brīef } & (1325) & \text { brěvity } \\ \text { clēar } & (1297) & \text { clărity }\end{array}$

Lahiri \& Fikkert argue that the motivation behind the alternation in vowel length is the optimization of the prosodic structure of these words. The preference for (a) maximal feet and (b) a complete syllable parse led to vowel lengthening is disyllabic words. This is referred to as Open Syllable Lengthening (cf. Lahiri \& Dresher 1999), as shown in (7a), and as vowel shortening in trisyllabic words (7b). A short vowel in the disyllabic forms in (7a), would be less preferred, as the foot only consists of a head, rather than a head plus a dependent, i.e. weak branch of the foot. The preference for heavy stressed syllables is a long noted tendency, known as Prokosch' Law (Prokosch 1939). However, words with short stressed vowels are nevertheless allowed, as shown in (6) and (7b), in which an initial heavy syllable would result in a prosodic structure in which the final syllable is left stranded. By shortening the initial vowel, this situation is improved resulting in an acceptable Germanic foot. 
(7) Open Syllable Lengthening and Trisyllabic Shortening

a.

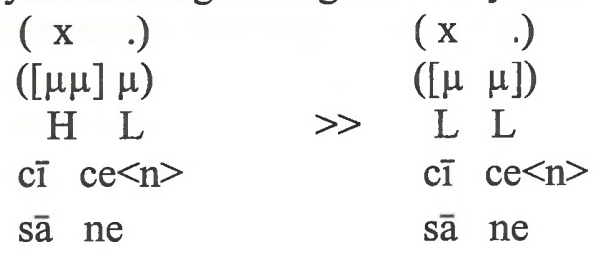

b.

$\begin{array}{ccc}(x \quad .) & & (x \quad .) \\ ([\mu \mu] \mu) & ([\mu \mu]) \mu \\ L L L & H L L \\ \text { cǐ ce nu } & & \text { cǐ ce nu } \\ \text { să ni ty } & & \text { să ni ty }\end{array}$

A number of interesting facts need to be mentioned. First, English did not borrow stress nor vowel length from the donor language. Latin words like perso:na 'person', which have a long stressed vowel in the penultimate syllable are borrowed with initial stress and a short penultimate vowel in Middle English persone (cf. Luick 1907: 33-38, Danielsson 1948: 37, Minkova 1997, Lahiri \& Dresher 1999, Lahiri \& Fikkert 1999). Second, Middle English no longer has inflectionally related nouns that differ in the length of their initial vowels. Pairs like those in (6a) no longer exist in Middle English and length distinctions in inflectionally related words have been leveled out (cf. Lahiri \& Dresher 1999). However, derivationally related pairs, as those in (6b) have survived into Modern English. In an analysis of contemporary English, Prince (1990) has argued that due to prosodic optimization trisyllabic words undergo trochaic shortening resulting in a moraic trochee, under extrametricality.

Given that Romance loans like sane - sanity adopted the native Middle English prosodic system upon entering the English language, there would be no reason to assume that at the same time other Romance loans that entered the language would not be incorporated into the native prosodic system. Let us now look at 'prefixed' Romance loans into Middle English. 


\section{Prefixed loans in Middle English}

Prefixed loans, such as abstráct $t_{\mathrm{V}}$ - ábstract $t_{\mathrm{N}}$, first occurred in Middle English. If the prosodic system at the time of borrowing was as described above, both nouns and verbs would have entered the language with initial stress. Therefore, we have to account for the fact that Romance verbs seem to have entered the language mostly with final stress. On the assumption that the prosodic system still had not changed, the only possible account can be that these words were considered prefixed. There were several reason for the speakers of Middle English to do so.

First, by the Middle English period, prefixed verbs with stressed particles (separable prefixed verbs), like those in (3b) had mostly disappeared. The only verbs with stressed prefixes were the verbs derived from nouns, as in (3c). Therefore, almost all native prefixed verbs that still existed in the language were inseparable and had stressless prefixes. Second, all native verbs were either strong or weak. The strong verbs were monosyllabic and had ablaut grades; the weak verbs were mostly denominative verbs with the -jan ending, such as árian 'to honor', bapian 'to bathe', célan 'to cool', etc., which had initial stress. Therefore, disyllabic verbal roots did not exist in the language. The only native disyllabic verbal forms were the prefixed verbs. The natural interpretation of foreign disyllabic verbs was therefore to consider them prefixed.

As we will see in the next section, one of the reasons for Halle \& Keyser (1971) to assume that these loans words - both nouns and verbs - all had final stress in early Modern English (by means of the Romance Stress Rule) is based on Levins 1570 pronouncing dictionary. Levins marks stress on a number of words, and mentions just a handful of pairs where the noun has initial and the verb final stress. The complete list found in Levins in given in (8) below:

(8) Complete list of noun-verb pairs which differ in stress in Levins

$\begin{array}{llll}\text { óutlawe } & 924 & \text { outláwe }^{8} & 10 . . \\ \text { míschiefe } & 1300 & \text { mischéefe } & 1330 \\ \text { quárel } & 1225 & \text { quarél } & 1390 \\ \text { rébel } & 1400 & \text { rebéll } & 1340\end{array}$




$\begin{array}{llll}\text { dývine } & <1303 & \text { divíne } & 13 . . \\ \text { députe } & 1405 & \text { depúte } & 1382 \\ \text { récorde }^{9} & 1300 & \text { recórde } & 1225\end{array}$

This can be taken to mean that these homophonous pairs, which only alternate in stress, were not common at that time, an interpretation given in Halle \& Keyser (1971). It could also be the case, however, particularly because many words in Levins are not marked for stress, that stress was mostly marked in Levins if it was not predictable. It is therefore of interest to investigate which word pairs are marked for stress in Levins to establish the predictable stress patterns.

The complete list of Romance verbs that receive initial main stress in Levins, just like the corresponding nouns, is given in (9).

(9) Initial-stressed Romance noun-verb pairs according to Levins (1570)

Noun Verb

a. Nouns attested earlier than verbs according to the OED

$\begin{array}{llll}\text { hónoure } & 1200 & \text { hónoure } & 1290 \\ \text { réason } & 1225 & \text { réason } & 13 . \\ \text { méritit } & 1225 & \text { mérit } & 1484 \\ \text { méasure } & 1225 & \text { méasure } & 1300 \\ \text { lánguage } & 1290 & \text { lánguage } & 1636 \\ \text { cóloure } & 1290 & \text { cóloure } & 1300 \\ \text { púrpose } & 1290 & \text { púrpose } & 1382 \\ \text { pásture } & 1300 & \text { pásture } & 1390 \\ \text { pórture } & 1305 & \text { pórture } & 1394 \\ \text { stómake } & <1340 & \text { stómake } & 1523 \\ \text { láyvel } & 1340 & \text { leývel } & 1440 \\ \text { pléasure } & 1368 & \text { pléasure } & 1559 \\ \text { férie } & 1377 & \text { féry } & 1496 \\ \text { múrmur } & 1381 & \text { múrmur } & 1386 \\ \text { éffect } & 1385 & \text { éffecte } & 1494 \\ \text { mórgage } & 1390 & \text { mórgage } & 1530 \\ \text { géllie } & 1393 & \text { géllie } & 1601 \\ \text { prómise } & 1400 & \text { prómise } & 1420 \\ \text { gésture } & 1410 & \text { gésture } & 1542\end{array}$




$\begin{array}{llll}\text { túmulte } & 1412 & \text { túmulte } & 1570 \\ \text { gárbage } & 1430 & \text { gárbage } & 1542\end{array}$

b. Nouns attested before verbs, where the verbs originally had final stress according to the OED

$\begin{array}{llll}\text { énvie } & 1280 & \text { énvie } & 1386 \\ \text { óutrage } & 1297 & \text { óutrage } & 1303 \\ \text { cáptive } & 1400 & \text { cáptive } & 1430 \\ \text { cónquest } & 1300 & \text { cónquest } & 1375\end{array}$

c. Verbs attested earlier than Nouns according to the OED

$\begin{array}{llll}\text { cómpasse } & 1300 & \text { cómpasse } & 1297 \\ \text { cóver } & 1300 & \text { cóver } & 1297 \\ \text { rével } & <1350 & \text { révell } & 1325 \\ \text { práctice } & 1494 & \text { práctice } & 1460 \\ \text { áccent } & 1538 & \text { áccent } & 1530\end{array}$

The verbs in (9a) have entered the language after their corresponding nouns, according to the OED. In (9c) the verbs are borrowed earlier than the nouns, and the verbs in (9b), which have initial stress according to Levins, seem to have had final stress earlier, according to the OED. Overwhelmingly, the verbs occurred later than the nouns, and one could argue that they could have been derived from the corresponding nouns, ${ }^{11}$ parallel to the native English verbs derived from nouns, as for example the verb ándswàrian 'to answer' from the noun ándswàru 'answer' in (3c).

In (10) all occurrences in Levins are presented in which both verbs and nouns are marked with final stress. Recall that the only nouns which did not bear stress on the prefix in Old English were the ones with unstressable prefixes, such as ge- in (3d), and those derived from inseparable verbs without changing stress, like those in (3e), as has been reported to be the case for debate. Although these prefixes which never bore stress were declining in Middle English, they have survived into Modern English, as in belief - believe. Here, it seems that in many cases the noun could have been derived from the verb, although this leaves the cases in (10b) unexplained. Possibly, the prefixes in (10b) were beginning to belong to the category of unstressable prefixes (cf. Lutz 1997 and footnote 6). 
(10) Final-stressed Romance noun-verb pairs according to Levins (1570)

Noun

Verb

a. Verbs reported to exist before nouns (OED)

$\begin{array}{llll}\text { excúse } & 1374 & \text { excúse } & 1225 \\ \text { exchange } & 1374 & \text { exchánge } & 1300 \\ \text { accómpt } & 1300 & \text { accómpt } & 1303 \\ \text { rewárde } & <1338 & \text { rewárd } & <1315 \\ \text { refúse } & 1330 & \text { refúse } & <1330 \\ \text { discharge } & 1460 & \text { dischárge } & <1330 \\ \text { mysúse } & 1398 & \text { mysúse } & 1374 \\ \text { disúse } & 1552 & \text { disúse } & 1375 \\ \text { distract } & 1624 & \text { distráct } & 1380 \\ \text { abúse } & 1538 & \text { abúse } & 1413 \\ \text { retrácte } & 1553 & \text { retráct } & 1432 \\ \text { extrácte } & 1549 & \text { extráct } & 1489\end{array}$

b. Nouns reported to exist before verbs (OED)

$\begin{array}{llll}\text { reléefe } & 1225 & \text { reléefe } & 1374 \\ \text { debáte } & 1300 & \text { debáte } & 1340 \\ \text { suspéct } & 1300 & \text { suspéct } & 1483 \\ \text { decrée } & 1303 & \text { decrée } & 1399 \\ \text { contráct } & 1315 & \text { contráct } & 1530 \\ \text { regárde } & 1340 & \text { regárde } & 1430 \\ \text { afféct } & 1374 & \text { afféct } & 1483 \\ \text { respéct } & <1391 & \text { respéct } & 1542 \\ \text { prospéct } & 1430 & \text { prospécte } & 1555 \\ \text { awárde } & 1300 & \text { awárde } & 1393\end{array}$

To summarize, Levins gives a number of word pairs in which both members have initial stress (9). Here it seems that the verbs are derived from the corresponding nouns, as overwhelmingly the nouns were borrowed before the corresponding verbs. For the word pairs with final stress on both members (10), the situation is less clear. However, although the words with stressless prefixes were declining, they still occur in the modern language, as in abúse (N, V). Apparently, the pattern was still strong enough in Middle English to allow new word pairs of this type, and the prefixes were presumably considered weak. Finally, Levins presents a small number of pairs with 
stress on the prefix in nouns, and on the verbal root in verbs, as in (8). Pairs with a stressed prefix for verbs and an unstressed one for nouns do not occur. Moreover, many prefixed words are not marked for stress. Given these facts, it seems not quite right to conclude that all disyllabic Romance nouns and verbs bore final stress. The situation was more complex than that. Although not all pairs were borrowed uniformly into the language, they nevertheless followed a pattern familiar from Old English.

Therefore, it is argued that Romance verbs entered the language as prefixed, because the language did not have disyllabic verbal stems. The only exceptions are verbs that are derived from nouns, which have stress on the prefix, as the verbs with a stressed separable prefix had ceased to exist in Middle English. Romance nouns, on the other hand, would under all analyses of Middle English stress receive stress on the prefix, unless the prefix was unstressable, and unless the noun was derived from the verb: in those cases the word would carry stress on the second part. Before turning to Dutch, let us first discuss previous accounts of stress assignment in Romance prefixed words.

\section{Previous accounts of prosodic structure in Romance loans}

\subsection{Halle \& Keyser (1971): The RSR and Stress Retraction}

In their monumental work on English stress, Halle \& Keyser (1971) sketch the development of the English stress system from Old English to Modern English. They assume the following stress pattern for Old English: stress is on the first syllable of the root, due to the Initial Stress Rule. Prefixed nouns ${ }^{12}$ subsequently undergo a stress retraction rule, which moves stress to the initial syllable. Due to massive borrowing from Romance, both from Latin and Anglo Norman, the Middle English stress system underwent several changes. First, next to the Old English stress rules, the Romance Stress Rule (RSR) was introduced into the language, given in (11). Second, the vocabulary was divided into two sets of words each with its own stress pat- 
tern: the unmarked native words underwent the Old English stress rules, the non-native set the RSR.

(11) Romance Stress Rule (RSR) (Halle \& Keyser 1971: 101)

$$
\mathrm{V} \rightarrow[1 \text { stress }] /\left[\mathrm{X}-\mathrm{C}_{0}\left(\left(\left[\begin{array}{l}
\text {-tense } \\
\mathrm{V}
\end{array}\right] \mathrm{C}^{1}{ }_{0}\right) \quad\left[\begin{array}{c}
- \text { tense } \\
\mathrm{V}
\end{array}\right] \mathrm{C}_{0}\right)\right]
$$

They acknowledge the fact that there are stress doublets in Middle English - particularly in the language of Chaucer (cf. Redford this volume). In their view this is due to the coexistence of two different stress rules: i.e. native words could be stressed by RSR, and vice versa non-native words by the Old English stress rules. However, and more importantly for us, they furthermore claim that the Romance stress doublets with different morphosyntactic categories, like those in (1) did not yet exist in Middle English. If initially-stressed Romance nouns (or verbs) occurred, they must have received stress by the Old English stress rules.

Moreover, even the early modern English dictionary of Levins (1570) do not have word pairs like permít $_{V}$ - pérmit ${ }_{N}$; these disyllabic word pairs usually have final stress in Levins according to Halle \& Keyser. ${ }^{13,14}$ Thus, as stress is no longer variable at the time of Levins, Halle \& Keyser argue that in Early Modern English all words receive stress by a uniform system. They claim that in Early Modern English the Old English Initial Stress Rule is given up and replaced by the RSR. Thus, both 'Romance' nouns and verbs receive final stress by the RSR. However, to account for the fact that words with final lax vowels, such as impórt, convérse, protést, receive final stress, they have to assume a prefix boundary $(=)$, which is not otherwise motivated. The Stress Retraction Rule is also changed to prevent its application to Romance disyllabic prefixed nouns, while still allowing stress retraction in the native disyllabic prefixed nouns. Thus, prefixed Romance nouns, [con=tráct] $]_{\mathrm{N}}$ have a different structure from prefixed native words, the later undergoing the stress retraction rule, as in [ánt\#giet $]_{\mathrm{N}}$. 
Halle \& Keyser claim that reliable evidence for stress retraction in Romance nouns only exists from 1634 on (based on Cooper's English Teacher). For early Modern English they suggest that both nouns and verbs (both native and non-native) are stressed by the RSR, but the nouns undergo the revised Old English Stress Retraction rule, which is now changed to apply to both [cón=tràct $]_{\mathrm{N}}$ and [ánt\#giet] $]_{\mathrm{N}}$. Two further remarks need to be made. First, Halle \& Keyser assume that nouns, like pérmit are derived from the corresponding verbs, and that these nouns therefore have the structure $\left[[\text { per }=\text { mit }]_{\mathrm{V}}\right]_{\mathrm{N}}$. However, from the dates given, we can infer that sometimes the verb occurred earlier than the noun. Moreover, the earlier initially stressed non-native nouns were assumed to have been separate lexical items, and were not derived from verbs (cf. footnote 14). Second, the stress retraction rule now becomes less restricted and may apply to all categories of words, except to non-nouns with a native prefix: that is, verbs like undergo and overtake remain finally stressed. Why the stress retraction rule for non-native words only applies in Modern English and not in Middle English remains "somewhat surprisingly" (Halle \& Keyser 1971: 112). It seems that the new early Modern English system is more analogous to the Old English pattern than the Middle English system was. Moreover, the stress retraction rule becomes even more general at the time of Walker's Pronouncing Dictionary (1791), where the stress retraction rule also applies to verbs, accounting for initially stressed verbs like vacate (1643), dictate (1592), although this does not seem to affect prefixed native and non-native verbs. They argue that there are two different stress retraction rules, with the choice between those two being lexically determined. However, it seems that native prefixed verbs never undergo stress retraction to the prefix.

There are a number of puzzling factors in this analysis. First, it seems that during the early Middle English period the lexicon was divided into two sets, which collapsed during early Modern English, but was reintroduced in Modern English. Second, under their analysis the Early Modern English stress system seems to bear more resemblance to the Old English stress system, than to the Middle English stress system. This is particularly due to the prevention of stress retraction in Romance prefixed disyllabic nouns in Middle English, pairs like those in (1) only being introduced in Modern English. 
Third, Romance prefixed nouns are assumed to be derived from the corresponding verbs, which is not obvious if we consider the times of their earliest occurrences according to the OED. Furthermore, as we saw above, trisyllabic (unprefixed) loans entered the language adopting the native prosodic system. Given this fact, it would be remarkable if other, i.e. disyllabic loans, took on their own foreign prosodic system.

The evidence for both the variation of stress in Middle English words and the non-variation of stress in words like the ones in (1), is questioned by Minkova (1997), among other people. She shows that variation was limited, and that the evidence points to 'an early and rapid adaptation of many of the Romance loans to the still dominant OE prosodic structure'.

\subsection{Minkova 1997: Different Grammar for different lexical strata}

Unlike Halle \& Keyser, Minkova argues that the stress system did not change dramatically from Old English to Middle English. What changed was that foreign words from Latin and Anglo-Norman entered the language, and as long as they were part of the peripheral lexical stratum, they obeyed the foreign stress rules. However, as soon as they become part of the core vocabulary of the language, they follow the native stress rules. Thus, variation in stress in loan words is due to the fact that they are in different lexical strata. This is, however, not her account of the different stress patterns in pairs like $a b s t r a ́ c t_{\mathrm{V}}-a_{b s t r a c t_{\mathrm{N}}}$, for which she assumes the Latinate stress system.

Minkova (1997) proposes an analysis of Old and Middle English stress in an Optimality Theoretical framework. In her view, the ranking of constraints determines the prosodic pattern of words in Old English, where ROOT STRESS - the first syllable of every lexical root carries stress - and INITIAL PROMINENCE - the left edge of a morphological category root is matched to the prosodic category of stress are unviolated. According to Minkova the native words all receive stress through the Old English stress system. Prefixed words have a special status: if the prefix is specified as part of the root, the prefixed word behaves as if it is monomorphemic and will receive ini- 
tial root stress; otherwise it is invisible for the constraint ROOT STRESS. In the example in (11), the prefix ge- is not specified as being part of the root, unlike most nominal prefixes, which are considered part of the lexical root, as shown in (12) for ánd $d_{\text {root }}$ swaru. However, verbal prefixes are not part of the root, as shown in (13) for forwiernan 'to refuse'.

(11) OE Constraint ranking

\begin{tabular}{|c|c|c|c|c|c|}
\hline $\begin{array}{l}\text { (ge).fór } \\
\text { 'died, } s g \text { ' }\end{array}$ & $\begin{array}{l}\text { Root } \\
\text { stress }\end{array}$ & $\begin{array}{l}\text { Initial } \\
\text { Prominence }\end{array}$ & Nonfin & WSP & $\begin{array}{l}\text { Right } \\
\text { Stress }\end{array}$ \\
\hline ge.fŏr & & & $* !$ & & \\
\hline gé.for & $* !$ & $?^{15}$ & & $*$ & $*$ \\
\hline
\end{tabular}

(12) OE Constraint ranking

\begin{tabular}{|l|l|l|c|c|c|}
\hline $\begin{array}{l}\text { ánd }{ }_{{ }_{\mathrm{r}}} \text { swaru } \\
\text { 'answer' }\end{array}$ & $\begin{array}{l}\text { Root } \\
\text { stress }\end{array}$ & $\begin{array}{l}\text { Initial } \\
\text { Prominence }\end{array}$ & Nonfin & WSP & $\begin{array}{l}\text { Right } \\
\text { Stress }\end{array}$ \\
\hline ándswaru & & & & & $* ! *$ \\
\hline andswáru & & $* !$ & & $*$ & $*$ \\
\hline andswarú & $* !$ & $* *$ & $*$ & $*$ & \\
\hline
\end{tabular}

(13) OE Constraint ranking

\begin{tabular}{|l|c|l|c|c|c|}
\hline $\begin{array}{l}\text { (for)wíernan } \\
\text { 'to refuse' }\end{array}$ & $\begin{array}{l}\text { Root } \\
\text { stress }\end{array}$ & $\begin{array}{l}\text { Initial } \\
\text { Prominence }\end{array}$ & Nonfin & WSP & $\begin{array}{c}\text { Right } \\
\text { Stress }\end{array}$ \\
\hline fórwiernan & $* !$ & & & & $* *$ \\
\hline forwíernan & & & & & $* !$ \\
\hline forwiernán & $* !$ & $* *$ & $*$ & & \\
\hline
\end{tabular}




\section{Paula Fikkert}

Crucially, Minkova's analysis can only account for the stressed prefix in nouns such as ándswaru 'answer' by assuming that 'prefixes can be root-like with respect to stress'. Otherwise the preferred form should have stress on the root, given the unviolated constraints INITIAL PROMINENCE and ROOT STRESS. Moreover, unstressed verbal prefixes must be invisible for the INITIAL PROMINENCE constraint. This information is part of the lexical representation. Under those assumptions, stress is uniformly assigned by the Old English constraint ranking, and differences between prefixed verbs and nouns are expressed in the lexical representations of nouns and verbs: prefixed nouns phonologically behave as underived, but prefixed verbs are morphologically composed of prefix plus root.

According to Minkova, Middle English stress differs from the Old English stress system only in the following aspect: Next to the Old English stress rules, there is another lexical stratum that conforms to the Latinate stress system. This system is composed of the same constraints, but they differ in ranking. In the Latin stress system NONFINALITY dominates INITIAL PROMINCE, and the WEIGHT-TOSTRESS PRINCIPLE (WSP) plays a role, and makes the system quantity sensitive. The crucial part of the Latinate constraint ranking is 'NONFINALITY $>$ WSP $>$ INITIAL PROMINENCE'.

In Minkova's analysis both the Old English and Latinate rankings produce the same results for disyllabic loans, because the highranked constraints NONFINALITY and INITIAL PROMINENCE are never in conflict in such words. She argues that, therefore, these words are borrowed with the native stress system, as shown in (14), adapted from Lahiri \& Fikkert (1999):

(14) Disyllabic Romance loans in English, German and Dutch

\begin{tabular}{lcll}
\hline English & $\begin{array}{c}\text { First recorded } \\
\text { in English }\end{array}$ & Dutch & $\begin{array}{c}\text { First recorded } \\
\text { in Dutch }\end{array}$ \\
\hline chánnel & 1300 & kanáal & 1376 \\
pánel & 1300 & panéel & 1280 \\
sátin & 1366 & satíjn & 1599 \\
tálent & 893 & talént & 1400 \\
métal & 1340 & metáal & 1240 \\
móral & 1380 & moráal & 1528
\end{tabular}




\begin{tabular}{llll} 
córal & 1305 & koráal & 1287 \\
prófit & 1325 & profijt & 1265 \\
sénate & 1205 & senáat & 1858 \\
pálace & 1290 & paléis & 1240 \\
jéalous & 1250 & jalóers & 1300 \\
básin & 1220 & basín & 1824 \\
fámous & 1400 & faméus & 1488 \\
móment & 1240 & momént & 1485 \\
páper & 1374 & papíer & 1361 \\
pátent & 1387 & patént & 1588 \\
prócess & 1330 & procés & 1295 \\
ráisin & 1382 & rozíjn & 1288 \\
vácant & 1290 & vacánt & 1569 \\
clóset & 1370 & closét & 1847 \\
\hline
\end{tabular}

Some Romance disyllabic words nevertheless have final stress in English. These words follow neither the native stress rules, nor the Latinate, but are in yet another stratum of the lexicon where they obey the Anglo-Norman stress rules, in which RIGHTWARD MAIN STRESS is high-ranked, and dominates both NONFINALITY and INITIAL PROMINENCE. These words are clearly perceived as foreign, according to Minkova. Once they become part of the core vocabulary stress shifts and becomes initial.

In non-prefixed inflected trisyllabic words there are only minor difference in the Old English and Latinate stress systems: Highranked INITIAL PROMINENCE and high-ranked NONFINALITY both dismiss the final syllable as a candidate for stress. However, according to the Old English stress system, INITIAL PROMINCE determines that stress is initial; the Latinate system leaves the decision between initial or medial stress to the WSP. If both syllables are of equal weight, the next constraint (INITIAL PROMINCE) decides (LLX, HHX), ${ }^{16}$ and these forms would receive initial prominence, although Minkova states that HHX-words have stress on the second syllable. If the second syllable is heavier than the first, stress will be on the penultimate syllable (L $\underline{H X})$, because of WSP. Thus, only for LHX (and in Minkova's view also HHX) words the Latin stress rules give different results than the Old English stress rule. There is, therefore, 
large overlap between the Latin and Old English stress systems, which made these loans so easy to incorporate.

Thus, Minkova (1997: 162) argues that 'The only change [from $\mathrm{OE}$ to $\mathrm{ME}$ stress] in the prosodic patterning was the newly developed differential treatment for disyllables and trisyllables. The former obeyed the Old English constraint ranking, the latter conformed either to the Old English pattern (continent, dividend, invalid, lavender, orchestra, vanity), or the late Latin pattern which respects NONFINALITY (imagine, omitted, possesses, tormented, united)". This newly differentiated treatment for disyllables and trisyllables, which are lexically marked and allow INITIAL PROMINENCE violations, is the crux in her account of the difference in stress in Romance nouns and verbs. Minkova assumes that nouns lost inflectional endings earlier than verbs, resulting in trisyllabic forms for verbs (contact+verbal inflection) versus disyllabic forms for nouns (contact). Both the Old English and the Latin constraint force initial stress on the nouns, but the Latinate stress system may result in penultimate stress for inflected verbs. The difference between nouns and verbs is therefore unrelated to their morphological structure; it is purely based on phonological grounds. To account for the stress differences in word pairs like abstráct $t_{\mathrm{V}}$ - ábstract $\mathrm{N}_{\mathrm{N}}$ the idea of convergence to the Old English system is therefore unnecessary and wrong according to Minkova.

The account given by Minkova raises a number of questions though. As we have seen in section 3, LHX nouns mostly had initial stress (as Minkova herself notes too), and Latinate HHX words were borrowed into the language with a short first syllable, resulting in a resolved moraic trochee: $([\mathrm{LH}] \mathrm{X})$. The need for the Latinate stress system is thus far from evident. Moreover, stress was already weight sensitive, given the possibility of a resolved moraic trochee.

Furthermore, Minkova argues that disyllabic and trisyllabic nouns are adopted according to the Old English stress pattern, whereas both disyllabic and trisyllabic verbs fall under the Latin stress system. However, why this is so, remains unclear. In particular, as nouns and verbs with native prefixes in $\mathrm{OE}$ (where inflectional endings were present for both nouns and verbs) have different lexical representations: stressed prefixes have root-like status, unstressed prefixes are invisible for the constraint rankings, it remains unclear why bor- 
rowed words would not follow a similar lexicalization process. That non-native word pairs exist with the same 'morphosyntactically conditioned' alternation is under this account purely accidental. Another fact to be explained is that when Middle English verbs lost their endings this did not effect stress. However, the prediction is that words would now be produced in the language with the 'nominal' stress pattern. ${ }^{17}$ Finally, in section 3 we have seen that vowel length alternations are maintained in derivationally related pairs, but that in inflectionally related pairs the vowel length alternation is leveled out. Here too, one would expect that the alternation, in this case of stress, would cease to exist after the loss of inflectional endings, as stress is purely assigned on the basis of phonological structure. This is, however, not the case.

Although Minkova is undoubtedly right about the fact that verbal inflections were maintained longer than nominal inflections, this is unlikely to be the source of the stress alternation in Romance verbnoun pairs, particularly given the strong native pattern of stress alternation in prefixed nouns and verbs. Moreover, the fact that other loans, particularly the trisyllabic ones discussed in section 3 , have adopted the native stress pattern, it seems but natural to adopt the analogy analysis for prefixed loans, too.

\section{Loans in Middle Dutch}

As mentioned in the introduction, Dutch borrowed word pairs like English abstráct $_{\mathrm{V}}-$ ábstract $_{\mathrm{N}}$ in quite a different fashion. First, nouns are borrowed with final stress. Second, the verb is borrowed with a stressed suffix. Recall from section 2 that at the time of borrowing, Middle Dutch had the Germanic foot, just like Old English. However, there were significant differences between Dutch and English in the middle period (cf. Fikkert 2000), which will be discussed in section 6.1 . 


\subsection{Comparing Middle English and Middle Dutch prosodic systems}

There is much uncertainty as to the exact stress system of Middle Dutch, as very little research has been carried out on the subject. All handbooks on Middle Dutch (cf. Franck 1910, Van Loey 1970, van Bree 1977, 1987) describe the Middle Dutch stress system as being similar to the older West Germanic system described in section 2: stress is word- or root-initial, unless the word is prefixed. However, most handbooks also note that the many French words and suffixes generally kept their original accent. This then weakened the feeling for accenting the first syllable and increased the chance for stress shifts in native words and word groups (cf. Van Loey 1970).

The question then is, whether or not Romance loans entered the language with Romance stress, unlike the situation in English. In Fikkert (2000) I argue against this analysis, on the basis of the study of stress alternations in the Middle Dutch text 'Sente Lutgart' (cf. Zonneveld, this volume). There are several types of words that showed variation to some degree and their structures are given in (15). The only disyllabic words with variable stress are the words with two heavy syllables, and thus two feet. Normally these are expected to have stress on the initial foot, but instead they sometimes have final stress. ${ }^{18}$ Words of the type LL, HL and LH invariably have initial stress, as these words form a single foot.

(15) Variation in prosodic forms

form expected structure
a. $\mathrm{HH}(\underline{\mathrm{H}})(\mathrm{H})$
b. HHL $(\underline{H})(H L)$

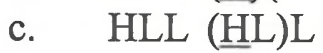
$(\underline{\mathrm{H}})(\mathrm{H})$ and $(\mathrm{H})(\underline{\mathrm{H}})$
(H)( $\underline{\mathrm{HL}})$ and sometimes $(\underline{\mathrm{H}})(\mathrm{HL})$
$(\mathrm{H})(\underline{\mathrm{LL}})$ and sometimes $(\underline{\mathrm{HL}}) \mathrm{L}$

attested structure

Of interest is that in the $\mathrm{HH}$ type words, most variation is found with the native monomorphemic and prefixed nouns. Suffixed nouns almost always have initial stress; Romance loans on the other hand invariably have final stress. Furthermore, almost all $\mathrm{HH}$ words with final stress have a heavy first syllable and a superheavy final syllable. It therefore seems that the heaviest foot receives main stress.

Trisyllabic words can be of several types. LLL and LHL words form one Germanic foot, and do not have variable stress (16a). As 
predicted, the structures in (16b) all have initial stress and no variation. ${ }^{19}$ There are only two patterns that have variable stress, which are given in (16c). Interestingly, these are exactly the structures that were prone to Trisyllabic Shortening in English.

(16) Middle Dutch dominant stress patterns
a. LLL
(LLL)
mǒneke 'monk'
LHL
(LHL)
cǒninge 'king'
b. $\mathrm{HHH}$
$(\underline{\mathrm{H}})(\mathrm{H})(\mathrm{H})$
wónderlíc 'strange'
HLH
(프)(H)
brūdegóem 'groom'
LHH
$(\underline{\mathrm{LH}})(\mathrm{H})$
běsechheit 'activity'
LLH
$(\underline{L L})(\mathrm{H})$
stédekíjn 'town, dim'
c. HHL
(H)(
HLL
$(\mathrm{H})(\underline{L L})$
abdésse 'abbess', ambáchte 'trade'
līchăme 'body', blīschăpe 'joy'

The forms in (16c) have in common with those in (16b) in that one foot is more complex then the other. However, they differ also significantly: the forms in (16b) have alternating stress, whereas the forms in (16c) contain a stress clash, which is usually resolved in favor of the most complex foot (cf. Dresher \& van der Hulst 1995, 1998).

The difference with Middle English, which favored Trisyllabic Shortening in these cases, is that whereas Middle English had no final stressed syllables, these did occur in Middle Dutch. Long vowels in closed syllables did probably did exist in the older stages of Dutch and German, as in OHG hanōm (dat. pl. 'cock') and zungūn ('tongue' nom./acc. pl.), and, Dutch also had many derivational (native) suffixes consisting of a superheavy syllable that bore at least secondary stress and are still superheavy to this day (cf. Dutch -loos, -heid, etc.). Note that the corresponding native suffixes were reduced syllables in English (-less, -ness). As final stress was possible in Dutch (but not in English), Romance loans could also enter the Dutch language with final stress, particularly as many of them were having superheavy final syllables. It seems, therefore, that in general 
superheavy syllables are exempted from the older West Germanic Final Defooting rule in Dutch. As mentioned in section 2, Final Defooting applied to all non-branching feet in English. In Dutch, the superheavy syllables seem to behave as if they were equivalent to a branching foot. On the other hand, heavy syllables in Dutch mostly had monosyllabic feet ending in $-\mathrm{VC}$, which were subject to destressing. This special status of monosyllabic -VC feet in Dutch has been preserved into Modern Dutch and is accounted for in many different ways: some claim that final syllables, except the superheavy ones, are made extrametrical (cf. Trommelen \& Zonneveld 1989). Others claim that a monosyllabic -VC foot is made extrametrical (cf. Lahiri \& Koreman 1988, Kager 1989).

To summarize, whereas Middle English has no final heavy or superheavy syllables, and no final stressed syllables, Middle Dutch seem to have all of these. However, superheavy final syllables bore stress. Moreover, if the final foot was the most complex foot in the word, it would attract main stress, as is the case with many disyllabic Romance loans, as shown in (2) and (14). The prosodic pattern of the language at the time of borrowing is therefore responsible for the final stressed nouns like contráct 'contract'. However, this does not account for the fact that the corresponding verbs borrowed the stressed infinitival suffix from French.

\subsection{Comparing Middle English and Middle Dutch prefixed verbs}

With respect to prefixed words, the Middle Dutch stress system was consistent with the older West Germanic system described in section 2: Stress is word- or root-initial, unless the word is prefixed. Just like Old English and Modern Dutch, all prefixed patterns described in (3) and (4) are attested in Middle Dutch. Thus, whereas prefixed nouns usually bore stress, unless preceded by an unstressable prefix, prefixed verbs could have both stressed and unstressed prefixes. Stress was therefore not a very unreliable factor for distinguishing nouns and verbs. It seems that the language chose another way to distinguish foreign nouns and verbs: by borrowing the infinitival suffix from French, which was always a branching foot, and therefore stress-bearing. 
Importantly, this was not the case for English: In Middle English separable prefixed words no longer existed, and therefore verbs with initial stressed prefixes no longer occurred in large numbers, whereas most prefixed nouns had stress on the prefix. Stress pattern and morphosyntactic class were therefore fairly reliably related.

A second distinction between prefixed verbs in English and Dutch is that prefixed verbs with unstressed prefixes were declining in English. As noted in the introduction, the common understanding of the decline of inseparable prefixed verbs is that the unstressed prefixed eroded, just like unstressed endings. Here the unstressable prefixes like ge-, were the first ones to disappear. However, as in English, Dutch unstressed endings also eroded, yet this was not the case with unstressed prefixes. Rather, in Middle Dutch sometimes prefixes have been added to words which did not have prefixes in the older stages of the language, as in the case of the past participle prefix ge-: the Middle Dutch forms worden, bracht, etc. are now realized as geworden and gebracht 'became, brought, past ptc.'. Stresslessness of the prefix itself can therefore not be a sufficient motivation for losing prefixes altogether.

Although the development of prosodic structures in the history of Dutch certainly needs to be studied in more detail, it seems clear that it differed from the Middle English stress system. The difference does not seem to be related to foot structure, because both have been argued to still have the Germanic foot in the middle stages. Rather, the differences are particularly due to differences in the preservation of vowel length in Dutch, versus the loss of length distinctions in English unstressed and final syllables. Due to these differences, Romance loans were borrowed differently in the two languages. Moreover, whereas English maintained a fairly reliable stressed-based distinction between nouns and verbs, this was not true in Dutch, because separable verbs with stress on the prefix were both frequent and productive in Dutch.

\section{Summary and conclusions}

In the older stages of the West Germanic languages there were two broad types of prefixed verbs: (a) verbs with stressed and separable 
(native) prefixes, and (b) verbs with unstressed and non-separable (native) prefixes. Whereas both types still exist in Dutch, Modern English no longer has verbs of category (a) and words of type (b) are declining. In the literature on prefixed verbs in English several reasons have been given for this decline of prefixed verbs (cf. Hiltunen 1983, Lutz 1997). The most common account for the decline of separable verbs in English is that this is due to the change in word order from SOV to SVO. The decline of inseparable prefixed verbs in English has been argued to be due to general erosion of unstressed syllables, often combined with semantic bleaching (cf. Lutz 1997). It has also been argued by some that it is due to the influence of French, which led to the borrowing of non-native words, both prefixed and unprefixed, which replaced the native words (cf. Marchand 1969). Moreover, the French influence on Dutch has also been considerable, but did not lead to the decline of prefixation. Rather, native prefixation is still very productive.

Instead, we have argued here that Romance loans into English were incorporated into the prosodic pattern of the language at the time of borrowing. As all disyllabic native verbs were prefixed, this was also the way disyllabic Romance verbs were analyzed. Prefixed disyllabic nouns usually have initial stress, and Romance nouns are borrowed similarly. The Middle Dutch prosodic system allowed final superheavy syllables with main stress, and this is how many Romance loans were borrowed.

Moreover, whereas prefixed nouns and verbs are fairly reliably distinguished by different stress patterns in English, this is not the case in Dutch which kept both initially stressed separable prefixed verbs and inseparable verbs with stress on the verbal root. As there was no predominant stress pattern for prefixed verbs, Romance verbs were borrowed with a finally verbal suffix, which often bore stress under the normal stress system at that time. Although many details of the analysis need further investigation, it has become clear that the prosodic systems of English and Dutch led to different ways in which Romance loans were incorporated. However, by and large, in both cases Romance loans were adapted into the native prosodic system of the language at the time of borrowing. 


\section{Notes}

* I would like to express my appreciation to Haike Jacobs, Astrid Kraehenmann, Aditi Lahiri, Frans Plank and Tania Zamuner for helpful comments on earlier versions of this paper. This research was funded by the Royal Dutch Academy of Science.

1. The date mentioned in (2) and elsewhere for Dutch words, denotes the first occurrence of a word according to van der Sijs (2001).

2. The meaning of the early attested word was not related to the verb: 'result of multiplying quantities'. The meaning 'product' only occurred in 1752.

3. It is not the case that the preverb changed into a postverbal particle: often a different particle than the preverbal one was used, as in OE atgo, atflee corresponding to ModE go to, to flee from, respectively.

4. If there is a direct relation between the decline of prefixed verbs in English and word order changes, it follows that if the word order did not change, as in Dutch and German, no decline of prefixed verbs is expected. Dutch and German have indeed retained both separable stressed, and inseparable, unstressed prefixed verbs.

5. The general view is that stressed prefixes have an independent semantic meaning unlike the unstressed ones; unstressed prefixed are claimed to have undergone semantic bleaching, and often have little meaning, or an idiosyncratic meaning: únderstandan 'to stand under' vs. understándan 'understand'.

6. Lutz (1997) argues that native prefixes were losing ground in Old and Middle English because of general phonological reduction rules. Prefixes with reduced vowels were particularly vulnerable to these reduction rules, which are based on phonological strength. This could lead to the loss of entire lexical units (thus, also prefixes), and to the replacement by a semantically suitable alternative. In the history of English two alternatives were available: verb-particle constructions and Romance loans.

7. Strang (1970) argues that the increase of Romance prefixed loans was triggered by the decline of native prefixed words, which caused a chain shift.

8. Outlaw and mischieve are now stressed on the initial syllable.

9. The OED remarks that originally stress was final, which remained as late as 19 th century.

10. According to the OED, the verb 'practice' previously had final stress.

11. For some verbs the OED explicitly mentions that they are derived from the nouns.

12. Halle \& Keyser (1971: p 94) notice that some prefixes never bear stress, and thus nouns with such prefixes never undergo the stress retraction rule. However, they leave open the question of specifically how to deal with prefixes like ge- and assume only that they are somehow marked as exceptions to the stress assignment rules.

13. Comparing (9) and (10) this is not so obvious. 
14. To account for the exceptional pairs given in (8), Halle \& Keyser assume that the nouns were separate lexical entries, not derived directly from the verbs, and presumably did not have a prefix $=$ boundary.

15. Minkova gives no violation here, and although it is not relevant as to optimal candidate is determined by the higher ranked constraint, ge- does not seem to be a root in itself.

16. Underlining refers to stress.

17. Moreover, verbs that enter the language after the loss of inflectional endings for verbs, should all have initial stress. This seems to be true.

18. Line final feet are not considered, because this position in general permits more variation.

19. As stress is alternating in these words it is impossible to distinguish between main and secondary stress on the basis of meter. These forms are therefore uninformative as to the location of main stress.

\section{References}

Aronoff, Mark

1976 Word formation in generative grammar. Cambridge, MA: MIT Press. Bree, Cor van

1977 Leerboek voor de historische grammatica van het Nederlands. Klanken vormleer met een beknopte grammatica van het Gotisch. Groningen: Wolters-Noordhoff.

1987 Historische grammatica van het Nederlands. Dordrecht: Foris. Brinton, Laurel J.

1988 The development of English aspectual systems. Aspectualizers and Campbell, A. post-verbal particles. Cambridge: Cambridge University Press.

1959 Old English Grammar. Oxford: Clarendon Press.

Chomsky, Noam \& Morris Halle

1968 The sound pattern of English. New York: Harper \& Row. Danielsson, B.

1948 Studies on the accentuation of polysyllabic Latin, Greek, and Romance loan-words in English. Stockholm: Almqvist \& Wiksells Boktryckeri.

Dresher, B. E. \& Harry van der Hulst

1995 'Head-dependent asymmetries in phonology'. In H. van der Hulst \& J. van de Weijer (eds.), Leiden in last: HIL phonology papers I. The Hague: Holland Academic Graphics. 401-431.

1998 'Head-Dependent asymmetries in phonology: complexity and visibility'. Phonology 15: 317-352. 
Dresher, B. Elan \& Aditi Lahiri

1991 The Germanic foot: metrical coherence in Old English. Linguistic InFikkert, Paula quiry 22. 251-286.

2000 'Prosodic variation in Lutgart'. In A. Lahiri (ed.), Analogy, levelling, markedness. Principles of change in phonology and morphology. Berlin: Mouton. 301-332.

Franck, J.

1910 Mittelniederländische Grammatik. Mit Lesestücken und Glossar. Leipzig: Chr. Hem. Tauchnitz.

Halle, Morris \& Samuel J. Keyser.

1971 English Stress. Its form, its growth, and its role in verse. New York: Harper \& Row.

Hammerich, Louis L.

1921 Zur Deutschen akzentuation. Copenhagen: Bianco Lunos Bogtrykkeri. Hayes, Bruce

1995 Metrical stress theory: Principles and case studies. Chicago: Chicago University Press.

Hiltunen, Risto

1983 The decline of the prefixes and the beginnings of the English phrasal verb. Turku: Turun Yliopisto.

Jespersen, Otto

1909 A Modern English grammar on historical principles, Part 1: Sounds and spelling. Heidelberg.

Kager, Rene

1989 A metrical theory of stress and destressing in English and Dutch. Dordrecht: Foris.

Kastovsky, Dieter

1996 'Verbal derivation in English: A historical survey. Or much ado about nothing'. In: Derek Britton (ed.), English historical linguistics 1994. Amsterdam/Philadelphia: John Benjamins.

Kingdon, R.

1958 The groundwork of English stress. London.

Kiparsky, Paul

1982 Explanation in phonology. Dordrecht: Foris.

Kluge, F.

1891 Vorgeschichte der altgermanischen Dialekte. In H. Paul (ed.), Grundriss der Germanischen Philologie. Band I. Strassburg: Karl J. Trübner. 300-406.

Krahe, H. \& W. Meid.

1969 Germanische Sprachwissenschaft. Berlin: Walter de Gruyter.

Kuhn, A.

1863 Review of C. W. M. Grein: Ablaut, reduplication und sekundäre Wurzeln der starken Verba dôn und iddja. Zeitschrift für vergleichende Sprachforschung 12. 142-145. 
Lahiri, Aditi \& B. Elan Dresher

1983-4 Diachronic and synchronic implications of declension shifts. The Linguistic Review 3. 141-163.

1999 'Open syllable lengthening in West Germanic'. Language 75: 678719.

Lahiri, Aditi \& Paula Fikkert

1999 'Trisyllabic shortening: past and present'. English Language and Linguistics. 229-267.

Lahiri, Aditi \& Jacques Koreman

1988 'Syllable weight and quantity in Dutch'. H. Borer (ed.), Papers from the West Coast Conference of Formal Linguistics 7. 217-228.

Lahiri, Aditi, Tomas Riad \& Haike Jacobs

1999 'Diachronic prosody'. In Hulst, H. G. van der (ed.), Word prosodic systems in the languages of Europe. Berlin: Mouton de Gruyter. 335421.

Levins, $\mathbf{P}$.

1969 Manipulus Vocabulorum (1570). Menston, England: Scolar Press.

Loey, A. van

1970 Schönfeld's Historische grammatica van het Nederlands. Zutphen: Thieme.

Lutz, A.

1997 Sound Change, Word Formation and the Lexicon: The History of English Prefix Verbs. English Studies 3. 258-290.

Luick, $\mathrm{K}$.

1907 'Beiträge zur englischen grammatik V. Zur quantitierung der romanischen lehnwörter und den quantitätsgesetzen überhaupt'. Anglia 30: 155.

Lutz, Angelika

1997 'Sound change, word formation and the lexicon: The history of the English prefix verbs', English Studies 3: 258-290.

Marchand, Hans

1969 The Categories and Types of Present-Day English Word-Formation. A Synchronic-Diachronic Approach. München: C. H. Beck'sche Verlagsbuchhandlung.

McCully, Chris \& Richard Hogg

1990 'An account of Old English stress'. Journal of Linguistics 26: 315339.

Minkova, Donka \& Robert Stockwell.

1994 Syllable weight, prosody, and meter. Diachronica 11 (1). 35-64.

Minkova, Donka

1997 'Constraint ranking in Middle English stress-shifting'. English Language and Linguistics 1: 135-175.

Oxford English Dictionary

1933 Edited by J. A. H. Murray et al. Oxford: Clarendon Press. 
Prince, Alan

1990 'Quantitative consequences of rhythmic organization'. In Ziolkowski, M., M. Noske \& K. Deaton (eds.) Parasession on the syllable in phonetics and phonology. Chicago: CLS. 355-398.

Prince, Alan \& Paul Smolensky

1993 Optimality theory: Constraint interaction in generative grammar. Ms. Rutgers University.

Prokosch, E.

1939 A comparative Germanic grammar. Linguistic society of America, University of Pennsylvania, Philadelphia.

Samuels, M. L.

1972 Linguistic evolution. With special reference to English. Cambridge: Scherer, W. Cambridge University Press.

1878 Zur Geschichte der deutschen Sprache. Berlin: Weidmannsche Buchhandlung.

Sijs, Nicoline van der

2001 Chronologisch woordenboek. De ouderdom en herkomst van onze woorden en betekenissen. Amsterdam/Antwerpen: Uitgeverij L.J. Veen.

Strang, Barbara

1970 A history of English. London: Methuen.

Strauss, S.

1982 Lexicalist phonology of English and German. Dordrecht: Foris.

Streitberg, Wilhelm, V. Michels \& Max H. Jellenick.

1936 Geschichte der indogermanischen Sprachwissenschaft. Teil II. Die Erforschung der indogermanischen Sprachen: Germanisch. Berlin: Walter de Gruyter.

Suphi, M.

1988 'Old English stress assignment'. Lingua 75: 171-202.

Sweet, $\mathrm{H}$.

1891 A history of English sounds. Oxford.

Trommelen, Mieke \& Wim Zonneveld

1989 Klemtoon en metrische fonologie. Muiderberg: Coutinho.Wright, J. \& E. M. Wright. (1925). Old English Grammar. Second Edition. Oxford: Oxford University Press.

Walker, J.

1791 A critical pronouncing dictionary and expositor of the English language. London.

Wright, J. \& E. M. Wright.

1925 Old English Grammar. Second Edition. Oxford: Oxford University Press.

1928 An elementary Middle English Grammar. Second Edition. London: Humprhey Milford Oxford University Press. 
Wurzel, W. U.

1984 Flexionsmorphologie und Natürlichkeit. Berlin: Akademie-Verlag. Zonneveld, Wim

1992/2000 Van Afflighem en Chaucer: Het leven van Sinte Lutgart als jambisch gedicht. Ruygh-Bewerp XVII. Vakgroep Nederlands, Universiteit Utrecht. Herzien uitgegeven, Münster: Nodus Publikationen (2000).

1993 '700 jaar Nederlandse klemtoon (en weinig veranderd)'. Spektator 22: 198-222.

Zonneveld, Wim, Mieke Trommelen, Michael Jessen, Curtis Rice, Gösta Bruce \& Kristjan Árnason

1999 'Wordstress in West-Germanic and North-Germanic languages'. In Harry van der Hulst (ed.), Word Prosodic Systems in the languages of Europe. Berlin: Mouton. 477-603. 